\title{
Pontential Germicidal Soap of Mangifera Indica Linn. (Mango) Fruit Peel Extract
}

\author{
Raquel L. Crebello', Maria Judy M. Somoray ${ }^{1,2}$ \\ 1Department of Physical Sciences, College of Science, \\ ${ }^{2}$ University Research and Development Services, \\ 1,2University of Eastern Philippines, University Town, Catarman, Northern Samar, Philippines
}

\begin{abstract}
How to cite this paper: Raquel L. Crebello | Maria Judy M. Somoray "Pontential Germicidal Soap of Mangifera Indica Linn. (Mango) Fruit Peel Extract" Published in International Journal of Trend in Scientific Research and Development (ijtsrd), ISSN: 24566470, Volume-3 | Issue-3, April 2019, pp.498-500, URL: http://www.ijtsrd.co $\mathrm{m} /$ papers/ijtsrd229 39.pdf

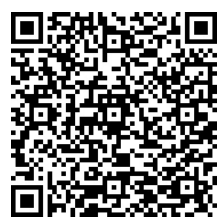
IITSRD22939
\end{abstract}

Copyright (c) 2019 by author(s) and International Journal of Trend in Scientific Research and Development Journal. This is an Open Access article distributed under the terms of the Creative Commons Attribution License (CC BY 4.0) (http://creativecommons.org/licenses/ by $/ 4.0$ )

\section{INTRODUCTION}

We live in a world filled with microbes, even the inside of our bodies takes a variety of organisms. This microorganism makes our Microbiota or flora. Microbiota are microorganisms that are normally associated with a particular tissue or organ. It is a genus of evergreen coniferous shrub in the cypress family Cupressaceae, containing only one species, Microbiota decussate (Funks, 1998).

Mangifera indica (Mango) is a large evergreen trees in the ancardiaceae family with a height of $10-45 \mathrm{~m} /$ dome shaped with dense foliage, typically heavy branched from a stout trunk. Anti-microbial soap is any cleaning product to which antimicrobial ingredients have been added. This chemical kills bacteria and microbes, but are no more effective at deactivating viruses than any other kind of soap or detergent, and they also kill nonpathogenic bacteria.

Mango species has adapted to wide variety of climates where it has become naturalized. Because fruits are eaten and dispersed by bats, hornbills, it has easily escaped from cultivation and established in practically every location where it has been intentionally introduced by humans (Bally, 2006; Orwa et al., 2009).
Anhwage, Ajibola and Oniye (2004) studied the possible source of soap. In their work, Moringa oliefera oil was evaluated as a potential for soap. The result of the study is that the iodine values of the oil of Moringa oleifera is high, and a requirement to make a soap.

Mabalaha et al (2007), reported that lower iodine value signifies low degree of unsaturation and the lesser the ability of the oil to become rancid by oxidation. Morever, Manzoor (2007) pointed out that lower the peroxide value indicated that the oil maybe more stable to oxidative degradation.

\section{METHODOLOGY}

Experimental method was used in this study. Extraction and making soap from Manginfera indica (Mango) was done in the Chemistry Laboratory Room of the College of Science, University of Eastern Philippines. Experiments were utilized to determine the physical and chemical properties as well as antimicrobial activity of Mangifera indica (Mango) fruit peel extract.

About 300 grams of ripe mango peel was weighed and extracted using the traditional juicer. For the preparation of lye solution, $150 \mathrm{~mL}$ of distilled water and 63 grams of 
sodium hydroxide $(\mathrm{NaOH})$ was mixed. Stir until the mixture dissolves. After preparation the lye solution, about $200 \mathrm{~mL}$ of coconut oil was added into the prepared lye solution and stirred the mixture until the texture is similar to a condense milk, then $50 \mathrm{~mL}$ of mango peel extract was added. It was stirred continuously until the mixture become sticky, then it was put into clean and dry molder to harden. Addition of scent was made for more pleasant odor.

\section{Determination of Physical Properties of Mango Soap}

The physical properties of the fruit peel extract were determined using the procedure that follows: Melting point, the small piece of mango peel soap was pushed to the open and of a capillary tube. The thermometer was attached on it with the use of a rubber band, it was placed on beaker with tap water and heated until the soap melts. pH level of Soap, a $\mathrm{pH}$ meter was used by dipping into the sample to determine the $\mathrm{pH}$. Solubility, the prepared mango soap was tested in water, benzene and acetone for about $2 \mathrm{~mL}$ which was poured into nine (9) different test tube filled with $0.5 \mathrm{~g}$ of prepared soap.

\section{Determine of Chemical Properties of Mango Soap}

Acid value was prepared with $2.8 \mathrm{~g}$ of sample were weighed and placed into an erlenmeyer flask, $12.5 \mathrm{~mL}$ of neutralized alcohol ( $25 \mathrm{~mL}$ ethanol $+25 \mathrm{~mL}$ ether) was added and mixed using stirring rod to dissipate warming on heat source if necessary. The sample was allowed to cool approximately and $1 \mathrm{~mL}$ of phenolphthalein was added. The burette was filled and titrated using $0.5 \mathrm{~N}$ methanolic potassium hydroxide to a faint pink color which remains for 30 seconds or more.

Iodine Value was prepared with $0.3 \mathrm{~g}$ of sample were accurately weighed and added into a $250 \mathrm{~mL}$ of chloroform, covering it immediately. It was mixed thoroughly by swirling and placed in the dark. Simultaneously a corresponding reagent blank was prepared containing $10 \mathrm{~mL}$ chloroform and $25 \mathrm{~mL}$ Hanus solution. The flask was placed in the dark with the test sample properly covered with cork stopper. After 60 minutes, $20 \mathrm{~mL}$ of potassium iodide was added using graduated cylinder, $100 \mathrm{~mL}$ of distilled water were added rinsing the neck and sidewalls of the flask during addition of water. Immediately the solution was titrated using $0.1 \mathrm{~N}$ sodium thiosulfate until the aqueous layer's color began to lighten. Approximately $3 \mathrm{~mL}$ starch solution was added and titrating continuously until the blue color of the aqueous layer begins to disappear. Towards the end of the titration, at intervals, the flask was covered, the shake vigorously to extract any iodine remaining in the chloroform layer. When the end point appears to have been reached, again it will be covered, then shake vigorously allowing the layers to separate and two drops of starch solution was added to verify that no blue color was formed in the aqueous.

Peroxide Value, 5.0g of sample was weighed into a 250 glass stopper Erlenmeyer flask. Using a graduated cylinder, $30 \mathrm{~mL}$ of the acetic-chloroform solution was added, swirl the flask until the sample was completely dissolved. Then $0.5 \mathrm{~mL}$ of saturated potassium iodide was added, the flask was covered and swirled for one minute. Immediately add $30 \mathrm{~mL}$ of distilled water, covered and shaken vigorously to liberate the iodine from the chloroform layer. The burette was filled with $0.1 \mathrm{~N}$ sodium thiosulfate. If the starting color of the solution was deep orange or if the solution was initially a light amber color, titrate slowly with mixing until the color lightens. With $1 \mathrm{~mL}$ of starch solution as indicator, titrate until the blue grey color disappear in the aqueous solution.

\section{Antimicrobial Sensitivity Test}

All the equipment was placed in an autoclave for sterilization. The Kirby Bauer antimicrobial test was used to determine the antimicrobial activity of the biocomposite films against $E$. coli and $S$. aureus. Each of the subculture pure isolates of the bacteria were aseptically harvested into the surface of the cultured plates by using sterile cotton swab. A filter paper for the control was soaked with the solution of Chloramphenicol (1:10). The filter papers soaked in the prepared solution and the control was aseptically and carefully impregnated into the surface of nutrient agar using a sterile pick up forceps. The disc was placed with a distance from each other. The inoculated plates were incubated at $37^{\circ} \mathrm{C}$ for $18-24$ hours. After the inoculation, the plates were inspected for the presence of any clear zone of the inhibition around the sample discs.

\section{RESULTS AND DISCUSSION}

The data gathered from a series of experimentation within three trials were analyzed and interpreted by the researcher according to the statement of the problems of this study.

Mangifera indica (Mango) peel was collected at Brgy. Narra, Catarman Samar. The result of the study are herein presented. The physical characterization in terms of color, melting point, odor, $\mathrm{pH}$ value, and solubility. The chemical characterization in terms of acid value, iodine value and peroxide value as well as its antimicrobial activity.

Table1. Summary of the results for physical properties

\begin{tabular}{|c|c|c|}
\hline \multicolumn{2}{|c|}{ Physical Properties } & \\
\hline \multicolumn{2}{|c|}{ Color } & Yellow \\
\hline \multicolumn{2}{|c|}{ Melting Point } & $74.67^{\circ} \mathrm{C}$ \\
\hline \multicolumn{2}{|c|}{ Odor } & Plec \\
\hline \multicolumn{2}{|c|}{$\mathrm{pH}$ value } & 12 \\
\hline \multicolumn{2}{|c|}{ Texture } & Smooth \\
\hline \multirow{3}{*}{ Solubility in } & Acet & Miscible \\
\hline & Benz & Imm \\
\hline & 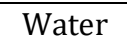 & Miscible \\
\hline
\end{tabular}

As shown in table 1, physical properties obtained from prepared soap has a color yellow, a melting point for an average of $74.67^{\circ} \mathrm{C}$, containing a pleasant odor, $\mathrm{pH}$ average of 12.54 and for the determination of solubility there were three solvents use namely water, acetone and benzene. The prepared soap is miscible for both acetone and water which indicates as polar while immiscible in benzene.

The result of the determination of the chemical properties are as follows: Acid Value which has an average of 104.47 implies that the fat has been stored in a suitable condition, Iodine value of 43.71 that indicates that there are more double bonds present in fat whereas peroxide value containing an average of 8 indicates that they are less liable in oxidative.

\section{Antimicrobial Activity}

The result on the determination of antimicrobial sensitivity using microorganism namely Escherichia coli and Staphylococcus aureus are shown in the figure. 


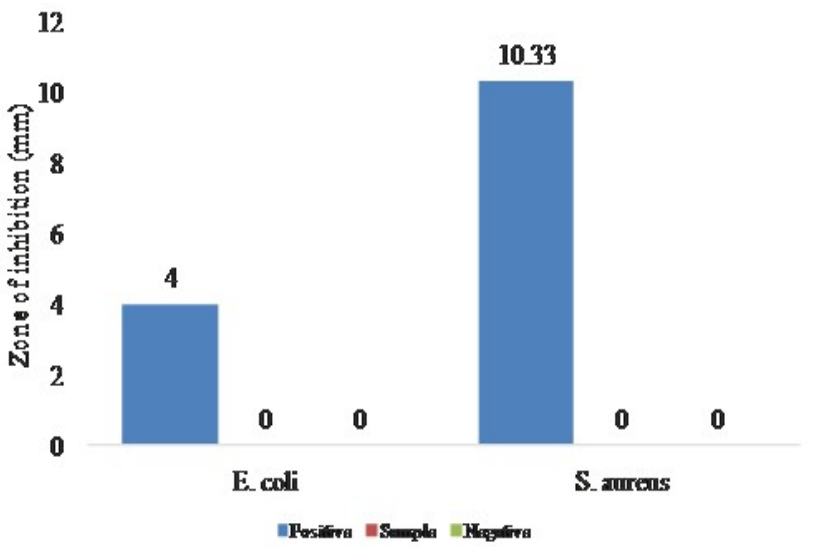

Figure1. Determination of Antimicrobial Sensitivity

In the figure 1 , it shows that based on the performed experiment on the anti-microbial sensitivity test, the prepared soap from mango peel does not have the capability to reduce the excrescency of the microorganisms namely Escherichia coli and staphylococcus aureus. There was no zone of inhibition in the sample soap and the negative control. Therefore, the prepared soap is not that qualified to kill the microorganisms E.coli and S. aureus.

\section{CONCLUSION}

The anti-microbial sensitivity test suggested that the prepared soap from mango peel extract does not have the capability to reduce the excrescency of the microorganisms namely Escherichia coli and Staphylococcus aureus, although it inhibited in positive control-chloramphenicol. Based on the conducted experiment, Mangifera indica (Mango) fruit peel extract is not comparable to the commercially available germicidal soap.

\section{References}

[1] Aquino LA. 2007. Extraction of sap from Jathropa curcas (Tubang-bakod) as potential ingredient in dishwashing liquid. Unpublished Research, College of Science, University of Eastern Philippines.

[2] Kale GD. 1985. Antimicrobial properties of soap containing fatty acids and esters. International Journal of Cosmetic Sciences.

[3] Narca AR. 2010. Germicidal soap from Artocarpo sheterophyllus (Jackfruit) seed oil. Unpublished Research, College of Science, University of Eastern Philippines.

[4] Oncepido JS. 2014. Moringa oleifera Lam. (Malunggay) seed extract as potential moisturizing addictive soap. Unpublished Research, College of Science, University of Eastern Philippines.

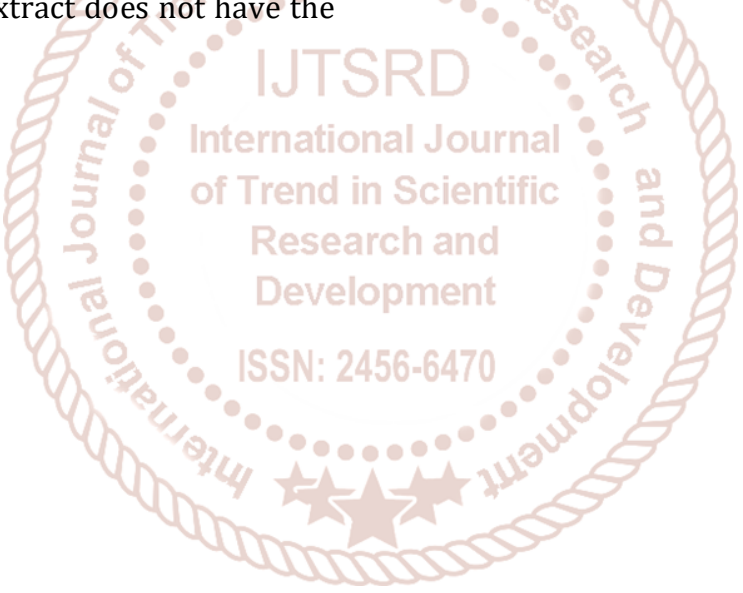

